\title{
Determination of Crop Co-efficient Values of Soybean (Glycine max [L.] Merrill) by Lysimeter Study
}

\author{
A. J. Mila*, A. R. Akanda and K. K. Sarkar \\ Irrigation and Water Management Division, Bangladesh Agricultural Research Institute (BARI), \\ Gazipur-1701, Bangladesh \\ *Corresponding author and Email: afrinbau@gmail.com
}

Received: 29 July 2016

Accepted: 12 December 2016

\begin{abstract}
Local level calibration of crop coefficient $\left(\mathrm{K}_{\mathrm{c}}\right)$ values is critical for regional level planning and allocation of water resources for irrigation. In this regard, an experiment was conducted at the Irrigation and Water Management Division of Bangladesh Agricultural Research Institute (BARI), Gazipur, in order to estimate crop coefficient values of soybean under the local climatic condition. An improved crop variety- BARI Soybean-6 was used in this experiment. The crop was grown under four irrigation treatments, allowing irrigation at an interval of 10, 15, 20 and 25 days. The treatments were so designed that drainage was allowed between the consecutive irrigations. Irrigation at 15 days interval produced the highest seed yield of $1.26 \mathrm{t} / \mathrm{ha}$ and was considered to be suitable for estimating seasonal crop evapotranspiration $\left(\mathrm{ET}_{\mathrm{c}}\right.$ ) and $\mathrm{K}_{\mathrm{c}}$ values. The seasonal highest cumulative $\mathrm{ET}_{\mathrm{c}}$ was 308.43 $\mathrm{mm}$ under this treatment. The $\mathrm{K}_{\mathrm{c}}$ values of soybean at initial, development, mid-season and late season stages were found as $0.67,1.46,1.59$ and 0.62 , respectively.
\end{abstract}

Keywords: Reference evapotranspiration, crop evapotranspiration, micro-lysimeter, Penman-Monteith method.

\section{Introduction}

Irrigation has now turned into a costly input for agricultural production worldwide due to increasing demand of water. The competition for scarce water resources is hard-felt in the subtropical agricultural lands that often face semi-arid conditions. For instance, the winter season in Bangladesh is characterized by semiarid conditions, resulting in an acute shortage of water. Under such scenario, efficient irrigation management is crucial for winter crops in this country. In order to achieve this, an effective irrigation schedule is of utmost importance that requires crop coefficient $\left(\mathrm{K}_{\mathrm{c}}\right)$ data. However, the customized crop coefficient data for many crops are still not available in Bangladesh. For instance, the crop coefficient data of soybean (Glycine max [L.] Merrill), an important oil seed crop of the country, is yet to be found out. Consequently, scientists depend on the generic values of $\mathrm{K}_{\mathrm{c}}$ provided by the Food and Agriculture Organization (FAO) of the United Nations (Allen et al., 1998).

To estimate crop evapotranspiration $\left(\mathrm{ET}_{\mathrm{c}}\right)$ for irrigation planning on a regional scale, the crop coefficient data is of prime importance. It is the ratio of $\mathrm{ET}_{\mathrm{c}}$ to reference evapotranspiration $\left(\mathrm{ET}_{\mathrm{o}}\right)$ of alfalfa grass. Crop coefficient represents 
crop specific water use and is essential for accurate estimation of irrigation requirement of different crops in an area. Crop coefficient values for a number of crops grown under different climatic conditions have been suggested by Doorenbos and Pruitt (1977). The variation of the crop coefficient during crop growing season is obtained experimentally (Pruitt et al., 1972; Jensen, 1974; Doorenbos and Pruitt, 1977; Burman et al., 1980; Wright, 1982; Pruitt et al., 1987). Although there are published $\mathrm{K}_{\mathrm{c}}$ values for different crops, these are commonly used in places where local data are not available. As these values vary from place to place, and also from season to season, there is a strong necessity for local calibration of $\mathrm{K}_{\mathrm{c}}$ values under specific climatic conditions (Tyagi et al., 2000). Such calibration will ensure proper irrigation scheduling and efficient water management of crops on a regional scale.

Although several agronomic experiments (e.g., Rahman et al., 2013a; Rahman et al., 2013b; Ahmed et al., 2014; Khan et al., 2014; Khan et al., 2015) were conducted with soybean in Bangladesh, none of them has reported the crop coefficient values. Lysimeter studies, in particular, have not been yet done for this important oilseed crop in Bangladesh. In consideration of these knowledge gaps in the literature, this study was undertaken with the objective of determining the crop coefficient values of soybean at its different growth stages.

\section{Materials and Methods}

An experiment on soybean cultivation was conducted in a micro-lysimeter installed at the research farm of Bangladesh Agricultural Research Institute, Gazipur, during the rabi season (November to March) of 2015-2016. The climate was warm and dry with average temperature of $22.5^{\circ} \mathrm{C}$. The maximum and minimum relative humidity, and maximum and average wind speed were $93 \%, 34 \%, 10.64 \mathrm{~m} / \mathrm{s}$ and $1.60 \mathrm{~m} / \mathrm{s}$, respectively. The highest rainfall of $25 \mathrm{~mm}$ occurred on 8 March 2016, and the highest solar radiation was $22.8 \mathrm{MJ} / \mathrm{m}^{2} /$ day
(Table 1). The soil of the experimental field was silty clay loam, with field capacity and bulk density of $29.5 \%$ and $1.50 \mathrm{~g} / \mathrm{cm}^{3}$, respectively.

A hybrid variety of soybean (BARI Soybean-6) was selected for the lysimeter experiment. Seeds were sown in a $1 \mathrm{~m} \times 1 \mathrm{~m}$ micro-lysimeter platform at a spacing of $0.30 \mathrm{~m} \times 0.10 \mathrm{~m}$ on 19 November 2015. The seeds were treated using Bavistin@ $2 \mathrm{~g} / \mathrm{kg}$ of seed. The same crop was grown surrounding the lysimeter tanks with a view to create a similar cropping environment as in the lysimeter (Figure 1). Recommended fertilizer doses (FRG, 2012) were applied and necessary intercultural operations were done as and when required. In order to reduce fruit fly infestation, Sumethion 57 EC @ 2ml/L of water was sprayed at 35, 47 and 17 days after sowing.

The drainage type micro-lysimeter contains four tanks each of area 1 square meter. The crop was grown in the lysimeter in a controlled environment since the lysimeter was hydrologically separated from the surrounding soil (Michael, 2014). When crops are grown under such conditions, there is no need for further replication as argued by Khan et al. (1993). The similar system was used by other researchers (Islam and Hossain, 2010; Mila et al., 2016) for estimating crop coefficient values of hybrid maize and sunflower. Our experiment comprised four treatments as:

$\mathrm{T}_{1}=$ Irrigation at 10 days interval allowing drainage until receive the next irrigation

$\mathrm{T}_{2}=$ Irrigation at 15 days interval allowing drainage until receive the next irrigation

$\mathrm{T}_{3}=$ Irrigation at 20 days interval allowing drainage until receive the next irrigation

$\mathrm{T}_{4}=$ Irrigation at 25 days interval allowing drainage until receive the next irrigation

Measured quantity of water was applied as irrigation to the crops grown in the lysimeter tanks by ensuring provision of adequate drainage. In addition, the soybean plots adjacent to the tanks were also irrigated (Figure 1). Drainage water from the lysimeter tanks was collected and measured using graduated 
cylinders. The crop evapotranspiration, $\mathrm{ET}_{\mathrm{c}}$, was calculated from the irrigation and drainage quantities by using water balance principle (Equation 1) (Itier et al., 1997). Prior to irrigation, soil moisture was measured in order to determine soil-water depletion during a particular time period. The crop evapotranspiration was calculated by using water balance equation given by:

$\mathrm{ET}_{\mathrm{c}}=\mathrm{W}_{\mathrm{a}}-\left(\mathrm{D}_{\mathrm{w}} \pm \Delta \mathrm{S}_{\mathrm{s}}\right)$

where, $\mathrm{ET}_{\mathrm{c}}$ is crop evapotranspiration during a specified time period $(\mathrm{mm}), \mathrm{W}_{\mathrm{a}}$ is applied water plus rainfall during the time period $(\mathrm{mm}), \mathrm{D}_{\mathrm{w}}$ is drainage water during the time period $(\mathrm{mm})$ and $\Delta \mathrm{S}_{\mathrm{s}}$ is stored soil moisture during the time period $(\mathrm{mm})$.

There are several methods for determining reference evapotranspiration, $\mathrm{ET}_{\mathrm{o}}$. Among them, Penman-Monteith method has been recommended for empirical determination of $\mathrm{ET}_{\mathrm{o}}$ using climatic data viz., temperature, humidity, sunshine duration and wind speed (Allen et al., 1998; Michael, 2014). According to Smith et al. (1992), FAO Penman-Monteith method gives more consistent $\mathrm{ET}_{\mathrm{o}}$ estimates and has been shown to perform better than other methods. In this study, reference evapotranspiration, $\mathrm{ET}_{\mathrm{o}}$, was estimated by using CROPWAT software that uses Penman-Monteith model to calculate $\mathrm{ET}_{\mathrm{o}}$. This model requires only insertion of location (latitude, longitude and elevation), and climate data (maximum and minimum air temperature, humidity, sunshine hour and wind speed).

The crop coefficient, $\mathrm{K}_{\mathrm{c}}$, was estimated by using the following formula:

$\mathrm{ET}_{\mathrm{c}}=\mathrm{K}_{\mathrm{c}} \times \mathrm{ET}_{\mathrm{o}}$

At 111 days after sowing, the data on plant height and number of branches per plant were recorded from 10 plant samples in each lysimeter. Pods were collected three times during the crop maturity stage as flowering and pod formation occurred simultaneously. Data for leaf area index (LAI) was collected during the crop period starting from vegetative stage. The yield and yield contributing data were collected during and after harvesting of the crop.

\section{Results and Discussion}

\subsection{Effect of irrigation on growth and yield}

Table 2 represents growth, yield and yield contributing attributes of BARI Soybean-6. Treatment $\mathrm{T}_{2}$ (irrigation at 15 days interval) produced the highest plant height, number of branches per plant, pods per plant and seed yield, while treatment $\mathrm{T}_{4}$ (irrigation at 25 days interval) gave the highest number of seeds per pod and 100-seed weight compared to the other three treatments. It (treatment $\mathrm{T}_{4}$ ) took maximum 7 to 10 days to get completely drainage and rest of days (15-18 days) its root zone was becoming dry prior to receive next irrigation. On the other hand, treatment $\mathrm{T}_{2}$ (irrigated at 15 days interval) got 8-10 days to receive the next irrigation. As a result, the soil moisture content of the lysimeter tank experienced minimal fluctuation within the range of available soil moisture (Figure 2b). This treatment $\left(\mathrm{T}_{2}\right)$ also gave the highest leaf area index (LAI) of 12.34 at 85 days after sowing (Figure 3). Treatment $\mathrm{T}_{4}$ was particularly devastating for the crop since the 25-days irrigation interval induced almost intolerable water stress to the crop in the tank as illustrated in Figure 2d. By contrast, treatment $\mathrm{T}_{1}$ produced the lowest yield among the treatments, probably, due to the fact that this treatment experienced frequent irrigation (total 10) during the growth period. As a result, soil was almost saturated during the crop period, which significantly increases pod number and seed number per plant but most of the seed was immature. It also increases insect infestation. Eventually, this condition was translated into lower yield of soybean. In fact, it took 5 to 7 days to complete drainage from the tanks. Thus, there were only 3 5 days left for this treatment to receive irrigation water again. So, the soil moisture condition in this treatment was within the limit of available soil moisture (ASM = FC-PWP) throughout the growing season (Figure 2a). 


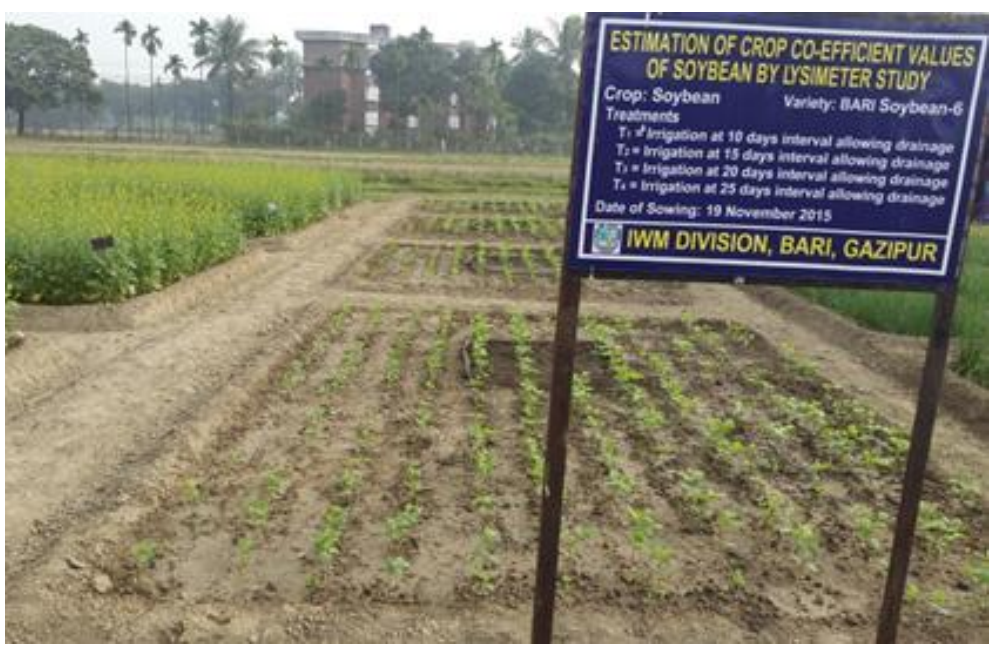

Figure 1. Photographic view of lysimeters in the experimental field. The age of plant was 26 days at the time of taking the photograph
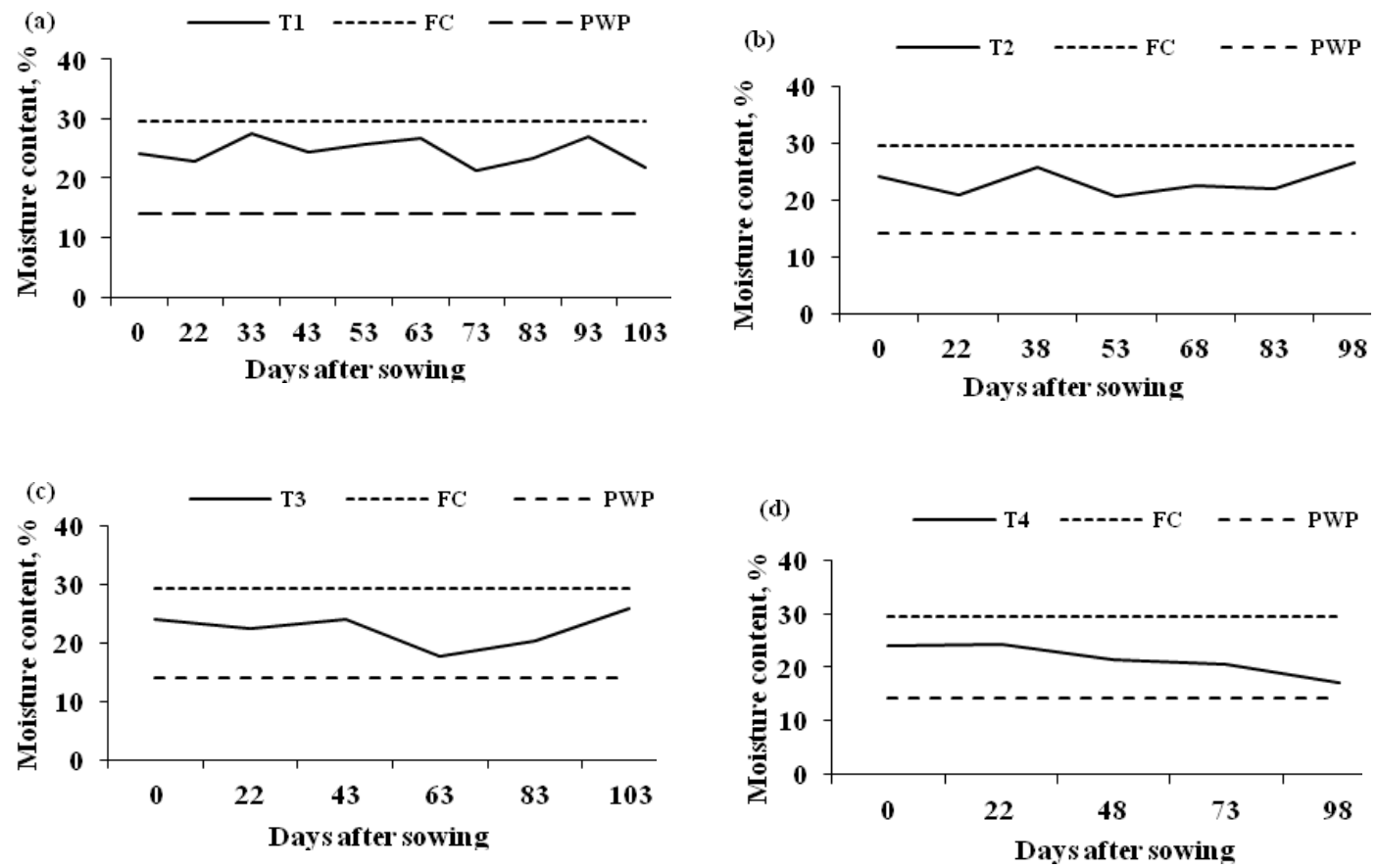

Figure 2. Soil-moisture content under different treatments during the crop period 


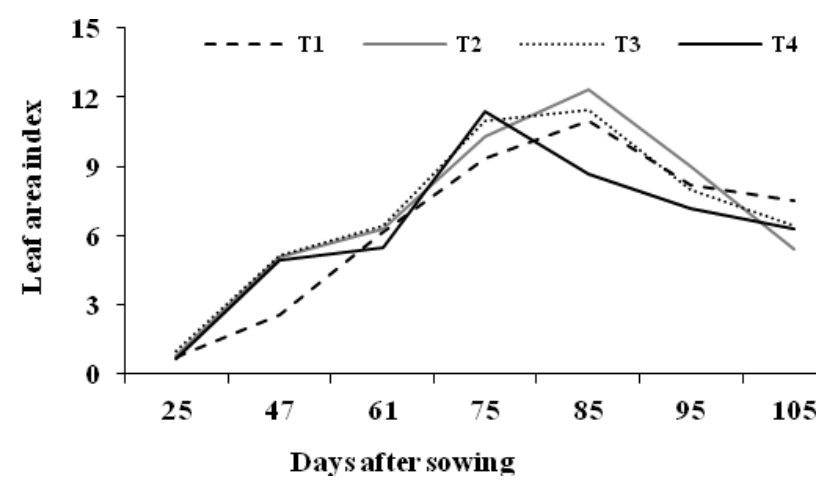

Figure 3. Effect of irrigation on leaf area index of soybean during the crop period

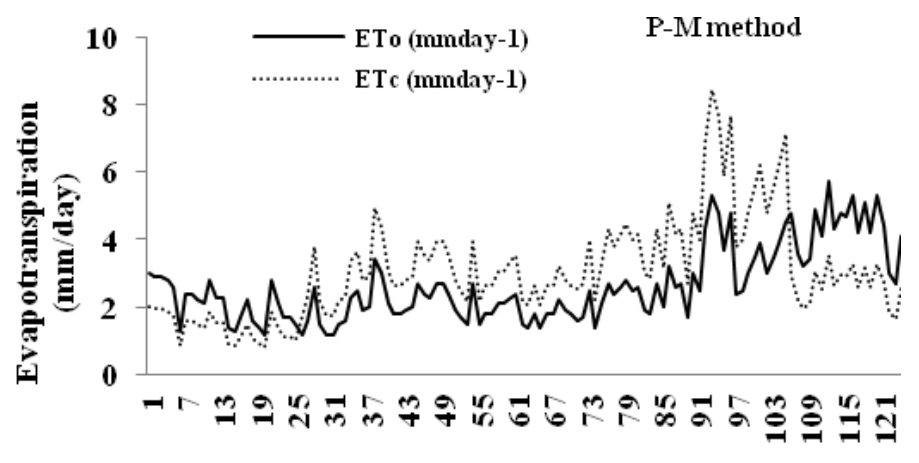

Crop growing period

Figure 4. Crop evapotranspiration $\left(\mathrm{ET}_{\mathrm{c}}\right)$ and reference evapotranspiration $\left(\mathrm{ET}_{\mathrm{o}}\right)$ of soybean during the growth period

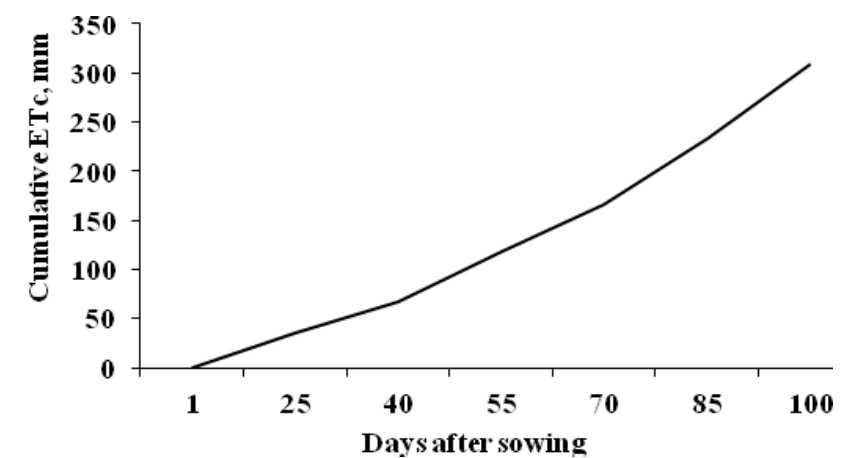

Figure 5. Cumulative crop evapotranspiration $\left(\mathrm{ET}_{\mathrm{c}}\right)$ of soybean during the crop growth period 
In contrast, in treatment $T_{2}$, soil moisture was within the limit of readily available moisture (RAM $=50-75 \%$ of ASM). This treatment $\left(\mathrm{T}_{1}\right)$ also showed the lowest LAI during the crop period (Figure 3). These results imply that the 15days irrigation interval was more favorable for the growth and yield of the crop compared to the other treatments. Therefore, the growing conditions associated with $\mathrm{T}_{1}, \mathrm{~T}_{3}$ and $\mathrm{T}_{4}$ cannot be taken as the reference regimes of crop growth as Doorenbos and Pruitt (1977) recommended that the optimum $\mathrm{K}_{\mathrm{c}}$ values should be obtained from the best growing plants, i.e., the plants producing the highest yield. In consideration of this, treatment $T_{2}$ was selected for determining the crop co-efficient values of soybean.

\subsection{Crop evapotranspiration, $\boldsymbol{E T}_{\mathrm{c}}$}

Table 2 represents crop evapotranspiration value of treatment $T_{2}$ where irrigation interval was 15 days. At 25 days after sowing, first irrigation was applied when leaf area index ranged from $0.65-$ 0.99 for treatment $\mathrm{T}_{1}$ to $\mathrm{T}_{4}$ (Figure 3 ). The last irrigation was applied at 100 days after sowing (LAI was 6.44) and the harvesting of soybean was done 23 days after that. Total $\mathrm{ET}_{\mathrm{c}}$ during the crop period was estimated to be $308.43 \mathrm{~mm}$. Karam et al. (2005) carried out a series of experiments on soybean crop under deficit irrigation condition. Their estimation showed that the total $\mathrm{ET}_{\mathrm{c}}$ was $800 \mathrm{~mm}$ and $725 \mathrm{~mm}$ during the year 2000 and 2001, respectively for the corresponding growing period of 140 and 138 days. The current experiment, however, produced much lower total $\mathrm{ET}_{\mathrm{c}}$ values compared to Karam et al. (2005). Also, Karam et al. (2005)'s growing period was at least 15 days more. On the other hand, the reported values of seasonal $\mathrm{ET}_{\mathrm{c}}$ value of soybean of Doorenbos and Pruitt (1977) ranged from 450 to $825 \mathrm{~mm}$, which are relatively closer to our $\mathrm{ET}_{\mathrm{c}}$ values.

Before harvest, a total rainfall of $5.0 \mathrm{~mm}$ was occurred during 119 to 122 days after sowing (Table 1). The negative sign in the value of soil moisture storage indicates that the plants extracted water from the soil in excess of that stored due to irrigation applications. By contrast, the positive sign indicates that water was stored in the soil in excess of initial water content.

\subsection{Crop coefficient $\left(K_{\mathrm{c}}\right)$}

The internationally recognized crop growth stages for the calculation of crop coefficients are initial, development, mid-season and late season stages (Allen et al., 1998). The duration of each stage depends on the length of growing season of a particular crop and climate (Doorenbos and Pruitt, 1977; Smith et al., 1992). The duration of crops with respect to stage of growth in the current experiment is provided in Table 4.

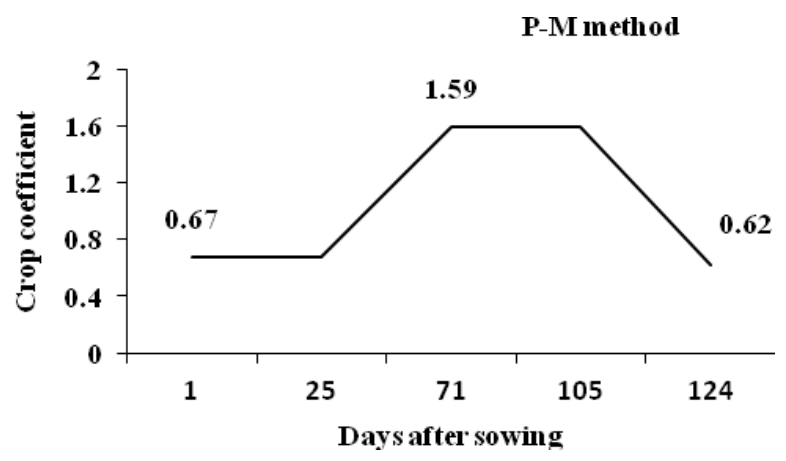

Figure 6. Crop coefficients $\left(\mathrm{K}_{\mathrm{c}}\right)$ of soybean during the growth period 
Table 1. Monthly weather parameter values of study area during the crop period

\begin{tabular}{|c|c|c|c|c|c|c|c|c|}
\hline \multirow[t]{2}{*}{ Month } & \multicolumn{2}{|c|}{$\begin{array}{c}\text { Temperature } \\
\left({ }^{\circ} \mathrm{C}\right)\end{array}$} & \multicolumn{2}{|c|}{$\begin{array}{c}\text { Relative } \\
\text { humidity }(\%)\end{array}$} & \multicolumn{2}{|c|}{$\begin{array}{l}\text { Wind speed } \\
(\mathrm{m} / \mathrm{s})\end{array}$} & \multirow{2}{*}{$\begin{array}{l}\text { Precipitation } \\
\quad(\mathrm{mm})\end{array}$} & \multirow{2}{*}{$\begin{array}{c}\text { Solar } \\
\text { radiation } \\
\left(\mathrm{MJ} / \mathrm{m}^{2} / \mathrm{day}\right)\end{array}$} \\
\hline & $\operatorname{Max}$ & Min & $\operatorname{Max}$ & Min & Max & Mean & & \\
\hline November & 30.45 & 16.33 & 94.58 & 84.67 & 1.56 & 0.79 & 0 & 15.33 \\
\hline December & 26.52 & 12.98 & 91.65 & 74.84 & 3.29 & 1.76 & 0 & 10.44 \\
\hline January & 23.43 & 13.95 & 91.35 & 66.81 & 2.67 & 1.51 & 8 & 12.32 \\
\hline February & 29.38 & 17.06 & 90.03 & 58.1 & 2.59 & 1.32 & 0 & 14.69 \\
\hline March & 33.08 & 19.9 & 88.71 & 53.62 & 4.29 & 2.36 & 41 & 18.34 \\
\hline
\end{tabular}

Table 2. Average growth, yield and yield contributing parameters of BARI Soybean-6 under four irrigation regimes

\begin{tabular}{lcccccc}
\hline Treatments & $\begin{array}{c}\text { Plant } \\
\text { height } \\
(\mathrm{cm})\end{array}$ & $\begin{array}{c}\text { Branch } \\
\text { number/ } \\
\text { plant }\end{array}$ & $\begin{array}{c}\text { Pod } \\
\text { number/plant }\end{array}$ & $\begin{array}{c}\text { Seed } \\
\text { number/ } \\
\text { pod }\end{array}$ & $\begin{array}{c}\text { 100-seed } \\
\text { weight }(\mathrm{g})\end{array}$ & $\begin{array}{c}\text { Seed yield } \\
(\mathrm{t} / \mathrm{ha})\end{array}$ \\
\hline $\mathrm{T}_{1}$ & 76.4 & 3.6 & 25.2 & 2.0 & 11.38 & 0.78 \\
$\mathrm{~T}_{2}$ & 86.4 & 3.9 & 29.6 & 2.0 & 11.82 & 1.26 \\
$\mathrm{~T}_{3}$ & 85.4 & 3.2 & 22.4 & 1.7 & 12.22 & 1.02 \\
$\mathrm{~T}_{4}$ & 74.3 & 3.2 & 16.7 & 2.2 & 13.27 & 0.98 \\
\hline
\end{tabular}

Table 3. Crop evapotranspiration, $\mathrm{ET}_{\mathrm{c}}$, of soybean grown under treatment $\mathrm{T}_{2}$ in the lysimeter tank during the growing season

\begin{tabular}{lcccc}
\hline $\begin{array}{l}\text { Days after } \\
\text { sowing }\end{array}$ & $\begin{array}{c}\text { Applied water } \\
(\mathrm{mm})\end{array}$ & $\begin{array}{c}\text { Drainage water } \\
(\mathrm{mm})\end{array}$ & $\begin{array}{c}\text { Change in soil water } \\
\text { storage }(\mathrm{mm})\end{array}$ & Crop ET (mm) \\
\hline 25 & 50 & 19.83 & 5.18 & 35.35 \\
40 & 25 & 1.11 & 7.76 & 31.65 \\
55 & 80 & 34.08 & 4.95 & 50.87 \\
70 & 65 & 25.09 & 8.36 & 48.27 \\
85 & 80 & 3.56 & -9.00 & 67.44 \\
100 & 80 & 2.19 & -2.96 & 74.85 \\
\hline Total & - & - & - & 308.43 \\
\hline
\end{tabular}

Here, Drainage water was calculated from after irrigation application up to before the next irrigation. In case of changing soil moisture storage, calculation was done change in moisture content before receive irrigation and after receive irrigation just prior to next irrigation at the root zone depth of known bulk density. 
Table 4. Length of growth stages (days) of soybean

\begin{tabular}{lccccc}
\hline Crop & $\begin{array}{c}\text { Growth } \\
\text { cycle }\end{array}$ & Initial (I) & Crop development (II) & Mid-season (III) & $\begin{array}{c}\text { Late season } \\
\text { (IV) }\end{array}$ \\
\hline Soybean & 124 & 25 & 45 & 35 & 19 \\
\hline
\end{tabular}

Table 5. Crop co-efficient values of BARI Soybean-6

\begin{tabular}{llccc}
\hline $\begin{array}{c}\text { Crop growth } \\
\text { stages }\end{array}$ & \multicolumn{1}{c}{$\begin{array}{c}\text { Duration } \\
\text { (Days) }\end{array}$} & $\begin{array}{c}\text { Crop ET } \\
(\mathrm{mm})\end{array}$ & $\begin{array}{c}\text { ET } \\
\text { o } \\
(\mathrm{mm})\end{array}$ & $\begin{array}{c}\text { Crop } \\
\text { co-efficient }\end{array}$ \\
\hline Initial & 25 (1-25 days after sowing) & 35.24 & 52.6 & 0.67 \\
Development & 45 (26-70 days after sowing) & 130.88 & 89.7 & 1.46 \\
Mid-season & 35 (71-105 days after sowing) & 162.34 & 102.1 & 1.59 \\
Late season & 19 (106-124 days after sowing) & 50.72 & 81.8 & 0.62 \\
\hline
\end{tabular}

Evapotranspiration and crop coefficients vary with the crop growth stages. Figures 4 to 6 illustrate the crop evapotranspiration, $\mathrm{ET}_{\mathrm{c}}$, reference evapotranspiration, $\mathrm{ET}_{\mathrm{o}}$, cumulative $E_{c}$ and crop coefficient, $K_{c}$, values of soybean at different growth stages. At the initial stage, the average $\mathrm{ET}_{\mathrm{c}}$ was $1.94 \mathrm{~mm} /$ day, which fluctuated throughout the growth period. It reached at the peak $(8.43 \mathrm{~mm} /$ day $)$ during the period of 93 days after sowing, and dropped down to1.86 $\mathrm{mm} /$ day at 122 days after sowing. Similarly, $\mathrm{ET}_{\mathrm{o}}$ being $2.90 \mathrm{~mm} /$ day at the primary stage fluctuated over 1.40 to $5.70 \mathrm{~mm} /$ day. The mid-season $\mathrm{ET}_{\mathrm{o}}$ was interestingly lower than the primary stage but it increased again to reach $8.43 \mathrm{~mm} /$ day prior to harvest (Figure 4). As can be seen from Figure 5, the cumulative $\mathrm{ET}_{\mathrm{c}}$ values increased steadily and reached to $35.35 \mathrm{~mm}$ at 25 days after sowing, $131 \mathrm{~mm}$ during 26-70 days after sowing and 178 $\mathrm{mm}$ during 71-105 days after sowing. During harvest, the cumulative $\mathrm{ET}_{\mathrm{c}}$ was $308.43 \mathrm{~mm}$.

The crop coefficient values were found to be $0.67,1.46,1.59$ and 0.62 at the four growth stages (Table 5). By taking average (Biswas et al., 2014) for the consecutive growth stages the $\mathrm{K}_{\mathrm{c}}$ values of three growth stages are illustrated in Figure 6 . The findings of several investigators conform to the findings of the current study. For instance, Karam et al. (2005) found that $\mathrm{K}_{\mathrm{c}}$ values of soybean were $0.62,1.0$ and 0.81 at the initial, pod formation and mature pod stage at Tal Amara Research Station, Lebanon. Allen et al. (1998) found the $\mathrm{K}_{\mathrm{c}}$ values of $0.40,1.15$ and 0.50 for the initial, mid-season and late-season stage, respectively. Doorenbos and Pruitt (1977) reported the $\mathrm{K}_{\mathrm{c}}$ values of soybean for mid-season and at harvest as 1.0 to 1.05 and 0.45 , respectively, depending on minimum relative humidity of $>70 \%$ and 1.1 to 1.15 and 0.45 , respectively, depending on minimum relative humidity of $<20 \%$. Doorenbos and Kassam (1979) reported $K_{c}$ values of $0.3-0.4,0.7-0.8$, 1.0-1.15 and 0.7-0.8 for initial, crop development, mid-season and late season stages, respectively. The $\mathrm{K}_{\mathrm{c}}$ values obtained in our experiment were much higher than the FAO recommended values except for the late season stage. Such variations are common and are expected because of the fact that different varieties perform differently in terms of their growth and development.

\section{Conclusions}

An experiment was carried out at the research field of Irrigation and Water Management Division, Bangladesh Agricultural Research Institute, Gazipur to know the crop evapotranspiration and crop coefficient values of 
soybean. Results showed that irrigation at 15 days interval including drainage within two consecutive irrigations gave the highest yield of soybean in this semi-arid region. Seasonal crop evapotranspiration of soybean was $308.43 \mathrm{~mm}$ when irrigation was provided at 15 days interval. The crop coefficient values of BARI Soybean-6 were $0.67,1.46,1.59$ and 0.62 at the initial, development, mid-season and late season stages, respectively. The estimated values of crop coefficient for soybean vary considerably over the growth stages from those recommended by FAO except for the late season stage. Nevertheless, the locally calibrated values of the crop co-efficient can be used for more reliable planning and distribution of regional water resources for irrigation.

\section{References}

Ahmed, S. U., Senge, M. and Ito, K. 2014. Response at different growth stages of soybean to deficit irrigation condition. Bangladesh Journal of Scientific Research, 27(2):165 - 174.

Allen, R. G., Pereira, L. S., Raes, D. and Smith, M. 1998. Crop evapotranspiration: guidelines for computing crop water requirements. FAO Irrigation and Drainage Paper No. 56, FAO, Rome, 300 pp.

Biswas, S. K., Hossain, M. A. and Akanda, A. R. 2014. Determination of crop co-efficient of garlic by lysimeter study.Annual Research Report, BARI, Gazipur 1701.

Burman, R. D., Nixon, P. R., Wright, J. L. and Pruitt, W. O. 1980.Water requirements. In: Design and Operation of Farm Irrigation Systems, (ed.) M. E. Jensen, St. Joseph, Mich, Transaction of American Society of Agricultural Engineers,189 $232 \mathrm{pp}$.

Doorenbos, J. and Kassam, A. H. 1979. Yield response to water. FAO Irrigation and Drainage Paper No. 33, FAO, Rome, Italy.
Doorenbos, J. and Pruitt, W. O. 1977. Guidelines for predicting crop water requirements. FAO Irrigation and Drainage Paper No. 24, FAO, Rome, Italy.

FRG (Fertilizer Recommendation Guide), 2012.Fertilizer Recommendation Guide, Bangladesh Agricultural Research Council, Farmgate, Dhaka-1215, 106 pp.

Islam, M. S. and Hossain, M. A. 2010.Determination of crop co-efficient of hybrid maize by lysimeter study. Bangladesh Journal of Agricultural Research, 35 (1):77-82.

Itier, B., Brisson, N., Doussan, C. and Tournebize, R. 1997. Bilanhydriqueen Agrometeorologie. Du Couvert Vegetal a la Region, INRA, Versailles, 383 - 397 pp.

Jensen M. (Ed.).1974. Consumptive use of water and irrigation requirements. Rep. Tech. Com. On Irrigation Water Requirements. Irrigation and Drainage Division, American Society of Civil Engineers, 227 pp.

Karam, F., Masaad, R., Sfeir, T., Mounzer, O. and Rouphael, Y. 2005. Evapotranspiration and seed yield of field grown soybean under deficit irrigation conditions. Agricultural Water Management, 75(3):226-244.

Khan, B. R., Mainuddin, M. and Molla, M. N. 1993. Design, construction and testing of a lysimeter for a study of evapotranspiration of different crops. Agricultural Water Management, 23:183-197.

Khan, M.S.A., Karim, M. A. and Haque, M. M. 2014. Genotypic differences in growth and ions accumulation in soybean under $\mathrm{NaCl}$ salinity and water stress conditions. Bangladesh Agronomy Journal, 17(1):4758.

Khan, M.S.A., Karim, M. A.,Haque, M. M., Karim, A.J.M.S. and Mian, M.A.K. 2015. Growth and dry matter partitioning in 
selected soybean (Glycine $\max$ L.) genotypes. Bangladesh Journal of Agricultural Research, 40(3):333-345.

Michael, A. M. 2014. Water requirement of crops and irrigation management. In: Irrigation Theory and Practice, ( $2^{\text {nd }}$ ed.), India, Vikas Publishing House, 478-553 pp.

Mila, A. J., Akanda, A. R., Biswas, S. K. and Ali, M. H. 2016. Crop co-efficient values of sunflower for different growth stages by lysimeter study. British Journal of Environment and Climate Change, 6(1):53-63.

Pruitt, W., Lourence, F. J. and von Oettingen, S. 1972. Water use by crops as affected by climate and plant factors. Californian Agriculture, 26(10):10 - 14.

Pruitt, W. O., Fereres, E., Kaita, K., and Snyder, R.L., 1987. Reference evapotranspiration $\left(\mathrm{ET}_{\mathrm{o}}\right)$ for California. Agriculture and Experiment Station Bulletin 1922.University of California, $16 \mathrm{pp}$ and 12 maps.

Rahman, M. M., Rahman, M. M.and Hossain, M. M. 2013a. Effect of sowing date on germination and vigor of soybean (Glycine $\max$ (L.) Merr) seeds. The Agriculturists, 11(1):67-75.

Rahman, M. M., Rahman, M. M.and Hossain, M. M. 2013b.Effect of row spacing and cultivar on the growth and seed yield of soybean (Glycine max [L.]Merrill) in Kharif-II season. The Agriculturists, 11(1):33-38.

Smith, M., Allen, R., Monteith, J. L., Perrier, A., Santos Pereira, L. and Sageren, A. 1992.Expert consultation on revision of FAO methodologies for crop water requirements.FAO, Land and Water Development Division, Rome, Italy, 60 pp.

Tyagi, N. K., Sharma, D. K. and Luthra, S. K. 2000.Determination of evapotranspiration and crop coefficients of rice and soybean with lysimeter. Agricultural Water Management, 45:41 - 54.

Wright, J. L. 1982.New evapotranspiration crop coefficients. Proc. of the American Society of Civil Engineers, Journal of the Irrigation and Drainage Division, 108(IR2):57-74. 